\title{
Imaging of SARS-CoV-2 infected Vero E6 cells by helium ion microscopy
}

\author{
Natalie Frese ${ }^{1}$, Patrick Schmerer ${ }^{2}$, Martin Wortmann ${ }^{3}$, Matthias Schürmann ${ }^{4}$, \\ Matthias König ${ }^{2}$, Michael Westphal ${ }^{1}$, Friedemann Weber $^{2}$, Holger Sudhoff ${ }^{4}$ \\ and Armin Gölzhäuser ${ }^{*} 1$
}

\section{Full Research Paper}

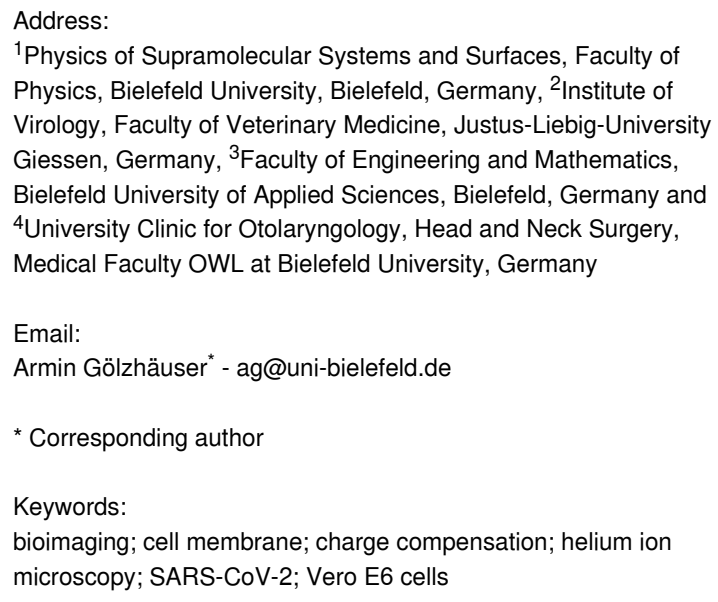

\author{
Beilstein J. Nanotechnol. 2021, 12, 172-179. \\ https://doi.org/10.3762/bjnano.12.13 \\ Received: 02 December 2020 \\ Accepted: 28 January 2021 \\ Published: 02 February 2021 \\ This article is part of the thematic issue "Ten years of the helium ion \\ microscope". \\ Guest Editors: G. Hlawacek and A. Wolff \\ (C) 2021 Frese et al.; licensee Beilstein-Institut. \\ License and terms: see end of document.
}

\begin{abstract}
Helium ion microscopy (HIM) offers the opportunity to obtain direct views of biological samples such as cellular structures, virus particles, and microbial interactions. Imaging with the HIM combines sub-nanometer resolution, large depth of field, and high surface sensitivity. Due to its charge compensation capability, the HIM can image insulating biological samples without additional conductive coatings. Here, we present an exploratory HIM study of SARS-CoV-2 infected Vero E6 cells, in which several areas of interaction between cells and virus particles, as well as among virus particles, were imaged. The HIM pictures show the threedimensional appearance of SARS-CoV-2 and the surface of Vero E6 cells at a multiplicity of infection of approximately 1 with great morphological detail. The absence of a conductive coating allows for a distinction between virus particles bound to the cell membrane and virus particles lying on top of the membrane. After prolonged imaging, it was found that ion-induced deposition of hydrocarbons from the vacuum renders the sample sufficiently conductive to allow for imaging even without charge compensation. The presented images demonstrate the potential of the HIM in bioimaging, especially for the imaging of interactions between viruses and their host organisms.
\end{abstract}

\section{Introduction}

The last decade of helium ion microscopy (HIM) was characterized by a rapid exploration of its sub-nanometer imaging and ion-beam nanofabrication capabilities in materials science and

engineering [1]. Although HIM soon proved to be a promising tool in the life sciences, the examination of biological samples by HIM proceeded at a much slower pace. In recent years, it has 
been used in the field of cell biology for imaging various human and animal cells. These include cartilage [2], cancer [3], liver [4], kidney [5] and stem cells [6], as well as fibrin fibers [7]. To visualize viruses and their host organisms, HIM has so far been applied to image T4 phage-infected E. coli bacteria [8], various phases of the life cycle of the bacterial predator Bdellovibrio bacteriovorus [9] and the vesicular structure of ethaneoxidizing archaea [10]. A comprehensive review on the subject of bioimaging with HIM has recently been published by Schmidt and co-workers [11].

In this work, we use HIM to investigate Vero E6 cells infected with the novel severe acute respiratory syndrome coronavirus 2 (SARS-CoV-2). Several members of the family Coronaviridae have been described in the human population and usually cause mild respiratory disease. SARS-CoV-2 demonstrated a worldwide spread causing a significant global public health emergency [12,13]. As of January 18th, 2021, more than 95 million cases worldwide have been confirmed with the infection and over two million infected patients have died [14]. African green monkey kidney Vero E6 cells have been reported to support SARS-CoV-2 replication in culture, while many more cell lines have been reported to be refractory to SARS-CoV-2 infection [15]. Both scanning electron microscopy (SEM) and transmission electron microscopy (TEM) have been used to image SARS-CoV-2 [16-20]. While TEM achieves unsurpassed resolution and can visualize macromolecular structures such as spike glycoproteins or transmembrane proteins [21], SEM provides topographic images of infected cells and virus particles distributed on their surface, albeit only after the samples have been coated with a conductive layer. In contrast, the HIM delivers a topographic image of the uncoated surface morphology of cells and virus particles, allowing one to identify and investigate sites at which a cell interacts with the virus. While its principle of operation is very similar to SEM, HIM utilizes a beam of positively charged helium ions $\left(\mathrm{He}^{+}\right)$instead of negatively charged electrons to excite and detect secondary electrons from the sample surface. Due to the high brightness and low energy spread of its atomically sharp gas field ion source, the smallest attainable focused spot size is about $0.3 \mathrm{~nm}$ [22] With its significantly smaller convergence angle compared to SEM, HIM achieves a much larger depth of field, which is particularly useful for imaging three-dimensional structures [22]. Due to their higher mass, $\mathrm{He}^{+}$ions penetrate deeper into the sample and do not spread as wide as electrons, resulting in a smaller escape volume of the secondary electrons and a higher surface resolution of the HIM, compared to the SEM [23]. A further benefit of HIM is its charge compensation capability during secondary electron detection. SEM imaging of biological specimen usually necessitates a thin conductive coating to prevent negative charge accumulation from the impinging elec- trons. Such coatings, albeit only a few nanometers thick, can significantly alter and conceal fine details of biological nanostructures [2], which is noticeable in SEM images of virus particles $[19,24]$. Since in the HIM positive charge accumulates on insulating samples, a low-energy electron flood gun can be used for charge compensation, which irradiates the sample with a diffuse beam of electrons. This eliminates the need for a conductive coating, and allows for a direct view on nanoscale structures $[6,25]$. Here, we demonstrate the benefits of highresolution HIM by imaging SARS-CoV-2 interacting with Vero E6 cells without any conductive coating. The presented images allow for the identification of SARS-CoV-2 virus particles, their interaction with the cell membrane and a distinction between virus particles bound to the cell surface from those lying on it.

\section{Experimental}

Vero E6 cells were cultivated in Dulbecco's modified Eagle's medium (Thermo Fisher Scientific) supplemented with 10\% fetal bovine serum (Capricorn Scientific) in a $5 \% \mathrm{CO}_{2}$ atmosphere at $37{ }^{\circ} \mathrm{C}$. SARS-CoV-2 (strain SARS-CoV-2 /München$1.2 / 2020 / 984$, p.2) [26] was grown on Vero E6 cells and titrated as described [27]. Infection experiments were done under biosafety level 3 conditions with enhanced respiratory personal protection equipment.

For HIM, cells were seeded onto coverslips placed in 24-well plates. The coverslips were previously sputter coated with $30 \mathrm{~nm}$ of gold to improve charge neutralization during HIM imaging. After $24 \mathrm{~h}$, nearly confluent monolayers were infected with SARS-CoV-2 at a multiplicity of infection (MOI) of approximately 1 or mock-infected using cell culture medium. Following an incubation period of $18 \mathrm{~h}$ in a cell culture incubator $\left(37{ }^{\circ} \mathrm{C}\right)$, cells were washed with $0.1 \mathrm{M}$ sodium cacodylate (NaCac, $\mathrm{pH} 7.4)$ and fixed in $2 \%(\mathrm{v} / \mathrm{v})$ glutaraldehyde, $2 \%(\mathrm{w} / \mathrm{v})$ paraformaldehyde in $\mathrm{NaCac}$ buffer at room temperature for $30 \mathrm{~min}$. After fixation at room temperature, the samples were transferred to the normal laboratory area and then fixed at $4{ }^{\circ} \mathrm{C}$ with fresh fixatives. The coverslips were subsequently washed and dehydrated in a graded series of ethanol $(50 \%, 70 \%, 95 \%, 99.5 \%(2 \times))$, transferred to water-free acetone and critical point dried in carbon dioxide.

HIM was performed with an Orion Plus microscope (Carl Zeiss) at an acceleration voltage of about $36 \mathrm{kV}$ and a working distance of $20 \mathrm{~mm}$. The spot control was set to 6 to obtain a beam current of 0.2 to $0.4 \mathrm{pA}$. To avoid charging effects during secondary electron detection, an electron flood gun was used after each line scan, if not stated otherwise, with a flood energy of $540 \mathrm{eV}$, flood time of $10 \mu \mathrm{s}$ and a focus of $107 \mathrm{~V}$. It should be mentioned that the flood gun parameters have to be opti- 
mized for each magnification level. All HIM images were recorded with $1024 \times 1024$ pixels. Before imaging, each sample was stored in the vacuum chamber of the microscope at $3.3 \times 10^{-7}$ mbar for at least $24 \mathrm{~h}$ to remove most volatile organic contaminants.

\section{Results and Discussion}

A comparison between a native and an infected Vero E6 cell at multiple magnification levels is shown in Figure 1. Figure 1a shows a sequence of four HIM images of native Vero E6 cells (mock-infected). Figure 1b displays a sequence of HIM images of Vero E6 cells after they have been exposed to SARS-CoV-2 at a multiplicity of infection of approximately 1 (MOI 1) and an incubation time of $18 \mathrm{~h}$. The surface of the infected cells is covered by a number of micrometer-sized vesicles and segments of cell membranes, which is a first indication that apoptosis occurred during viral replication. Regularly shaped particles below $100 \mathrm{~nm}$ diameter on the cell membrane shown in Figure $1 b_{4}$ were only abundant on the cells of the MOI 1 sample and were therefore identified as SARS-CoV-2 virus parti- cles. This is in accordance with a study of Bojkova et al. [28], which demonstrated the presence of newly synthesized viral particles of SARS-CoV-2 even $10 \mathrm{~h}$ after initial infection. The cell membrane of the infected cell is covered with the virus particles, which are predominantly spherically shaped. Holes in the cell membrane, illustrated in Figure $1 b_{4}$ and Figure S1 of Supporting Information File 1, have previously been observed in uncoated mammalian cells and indicate lipid nanodomains or caveolea [6]. Figure 1c shows an evaluation of the virus particle size in five arbitrarily chosen regions on the MOI 1 sample resulting in an average diameter of the virus particles of $75 \pm 13 \mathrm{~nm}$, noting that this value has been obtained from viruses after fixation and critical point drying.

As $\mathrm{He}^{+}$ions can penetrate several hundred nanometers into the sample [29], the outer rim of the cells appears brighter because the ions pass through the cells and generate additional secondary electrons at the back of the cells and in the gold-coated specimen slide [30]. The edges appear brightest where the cells bend upwards from the substrate. The edge resolution in two
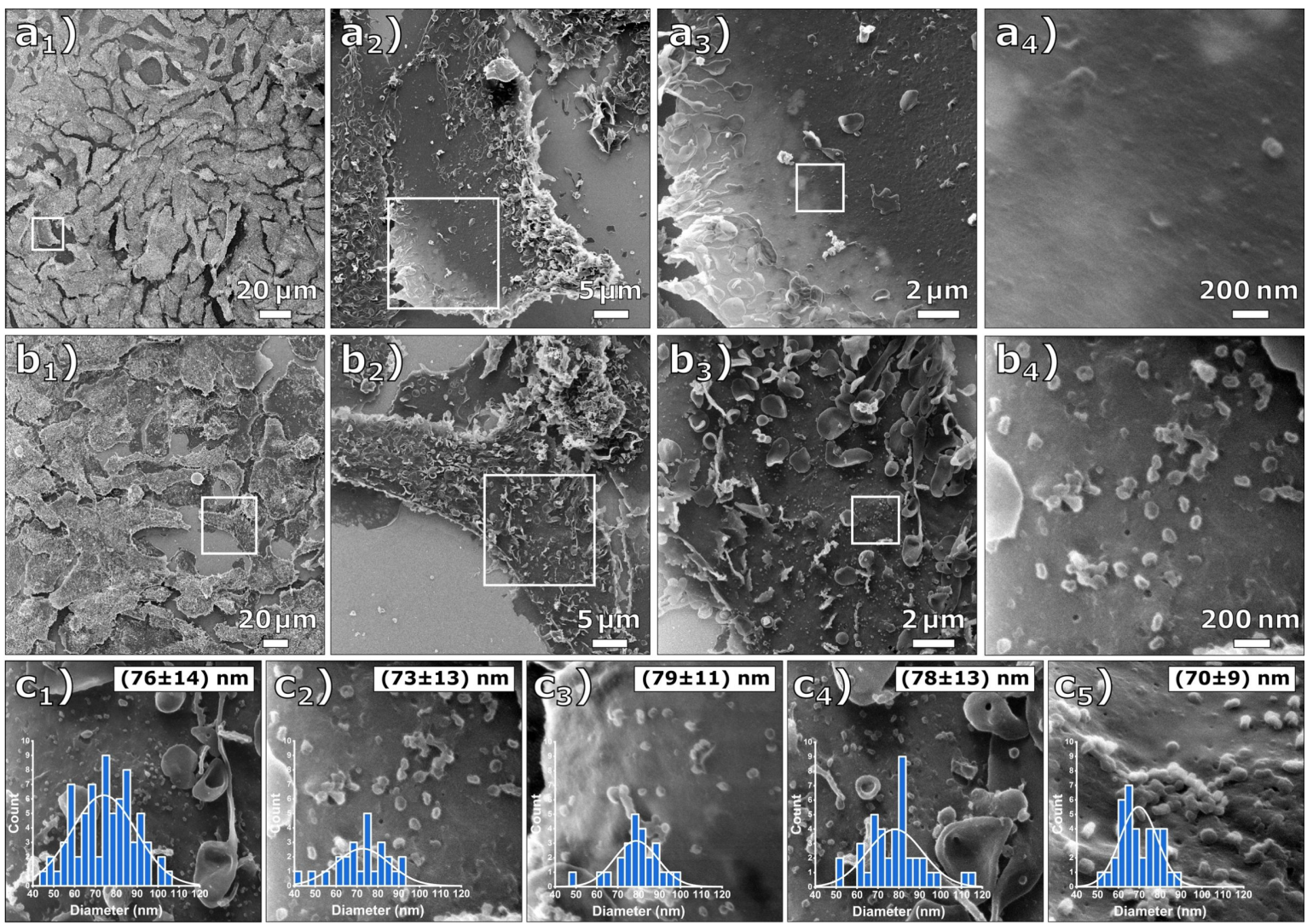

Figure 1: Comparative HIM images of Vero E6 cells that were mock-infected and infected at MOI 1. (a $\left.a_{1-4}\right)$ Mock-infected cells at different magnifications (FOV $200 \mu \mathrm{m}, 45 \mu \mathrm{m}, 15 \mu \mathrm{m}$, and $1.7 \mu \mathrm{m}$ ) and ( $\left.\mathrm{b}_{1-4}\right)$ cells infected at MOI 1 at different magnifications (FOV $250 \mu \mathrm{m}, 45 \mu \mathrm{m}, 15 \mu \mathrm{m}$, and $1.7 \mu \mathrm{m})$. The cell membrane is covered with the virus particles. $\left(c_{1-5}\right)$ Determined virus particle diameter distributions. The inserted histograms show the respective image evaluation with normal distribution, mean value, and standard deviation. The average diameter of all evaluated images is $75 \pm 13 \mathrm{~nm}$. 
highly magnified images, shown in Figure S2 of Supporting Information File 1, has been determined by plotting the corresponding gray-scale values over the edges of two holes, resulting in values of 1.3 and $2.1 \mathrm{~nm}$. The edge resolution of the images is determined by an interplay between the size of the focused $\mathrm{He}^{+}$beam and the widening of the beam within the sample material. The obtained values are typical for biological materials $[6-8,11]$.

An effect frequently occurring during HIM imaging with charge compensation can be observed in the sequence of HIM images shown in Figure $2 \mathrm{a}_{1-3}$, where a location on a MOI 1-infected Vero E6 sample was first imaged at a field of view (FOV) of $23 \mu \mathrm{m}$ (Figure $2 \mathrm{a}_{1}$ ), followed by two higher magnification images with a FOV of $4.5 \mu \mathrm{m}$ and a FOV of $1 \mu \mathrm{m}$ (Figure $2 \mathrm{a}_{2}$ ). Figure $2 \mathrm{a}_{3}$ shows the same region as Figure $2 \mathrm{a}_{1}$, but the parts that were previously imaged at high magnification (FOV of $4.5 \mu \mathrm{m}$ ) with a dose of $1.4 \times 10^{16}$ ions $/ \mathrm{cm}^{2}$ appear noticeably brighter. This is caused by $\mathrm{He}^{+}$beam-induced carbonaceous deposits resulting in a thin conductive coating. In addition to the improved conductivity of the specimen, the deposited layer may contribute to the electron density of the surface, thus increasing
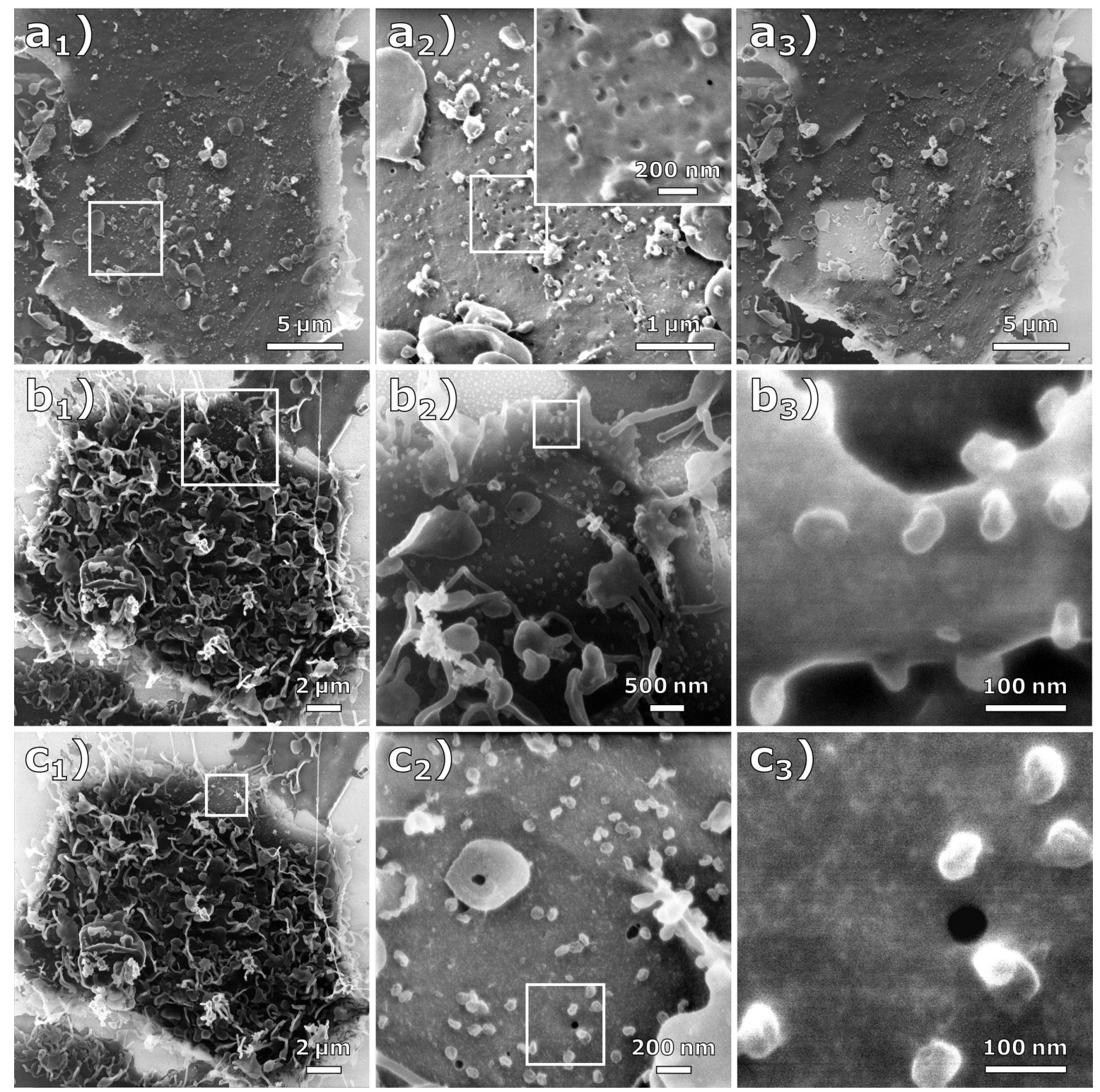

Figure 2: Effect of carbon deposition during HIM imaging. $\left(\mathrm{a}_{1}\right) \mathrm{HIM}$ image (FOV $20 \mu \mathrm{m}$ ) of a cell infected at MOI 1 with charge compensation. $\left(\mathrm{a}_{2}\right)$ HIM images at high magnification (FOV $4.5 \mu \mathrm{m}$ and $1 \mu \mathrm{m}$ ) with charge compensation. $\left(\mathrm{a}_{3}\right)$ The same image section as $\left(\mathrm{a}_{1}\right)$ after imaging the regions in $\left(a_{2}\right)$. Due to increased conductivity, this region appears significantly brighter than the rest of the image. ( $\left.b_{1-3}\right) H I M$ images of a cell infected at MOI 1 at different magnifications (FOV $20 \mu \mathrm{m}, 5 \mu \mathrm{m}$, and $450 \mathrm{~nm}$ ) with charge compensation. ( $\left.\mathrm{c}_{1-3}\right)$ HIM images of the same cell (FOV $20 \mu \mathrm{m}$, $2 \mu \mathrm{m}$, and $450 \mathrm{~nm}$ ) after imaging the magnified sections in $(b) .\left(c_{1}\right)$ and $\left(c_{2}\right)$ were imaged with and $\left(c_{3}\right)$ was imaged without charge compensation. 
secondary electron yield. This effect, commonly referred to as electron- and/or ion beam-induced deposition, is commonly observed in charged-particle microscopes. In electron microscopes, deposition rates of up to $3 \AA / s$ at high current densities have been reported. As the deposition rate quickly reaches an equilibrium with rising current density, it can be assumed that the limiting factor is the density of residual hydrocarbons in the vacuum [31]. In the HIM, residual gas as well as the specimen itself are considered the main contributors of hydrocarbons $[32,33]$. Due to the much larger mass of $\mathrm{He}^{+}$ions compared to electrons, their sputter rate is typically much higher. Since organic compounds are ablated from the sample surface, hydrocarbon deposition is likely to be more pronounced when imaging biological samples in HIM. A schematic illustration of this effect can be seen in Figure S3 of Supporting Information File 1.

Figure $2 b_{1-3}$ shows an infected Vero E6 cell at different magnification levels. Figure $2 b_{3}$ depicts the highest magnification (FOV $450 \mathrm{~nm}$ ) of the cell seen in Figure $2 b_{1}$, showing the virus particles on top of the cell membrane in a side view. Note that after the zoom-out in Figure $2 c_{1}$, the previously imaged regions appear again brighter. After imaging Figure $2 \mathrm{c}_{2}$ with a dose of $1.9 \times 10^{17}$ ions $/ \mathrm{cm}^{2}$, the flood gun was turned off, which allowed imaging of Figure $2 c_{3}$ without any external charge compensation. From the quality of this image, it can be inferred that the deposited carbon layer rendered the sample sufficiently conductive. However, small structures are still visible on the membrane surface, which may originate from surface topography or material contrast. The deposited carbon film is presumably thinner than typical conductive metal or carbon coatings for SEM imaging, and it does not show any surface masking and clustering as seen on the gold substrate in the upper left of Figure $2 b_{2}$. The energy of the incident hydrocarbons is much lower compared to the energy of sputter-deposited metals. However, it is possible that this unintended, but sometimes useful, carbon deposition can be reduced by HIM imaging in ultrahigh vacuum [34-36].

The cell structures shown in the HIM images of Figure 3a are sharply resolved over tens of micrometers, which demonstrates the high depth of field of HIM compared to SEM [37]. In image $3 \mathrm{a}_{3}$, at the surface of the cell, a cluster of virus particles seems to be bound to the cell membrane (arrow). We suggest that this
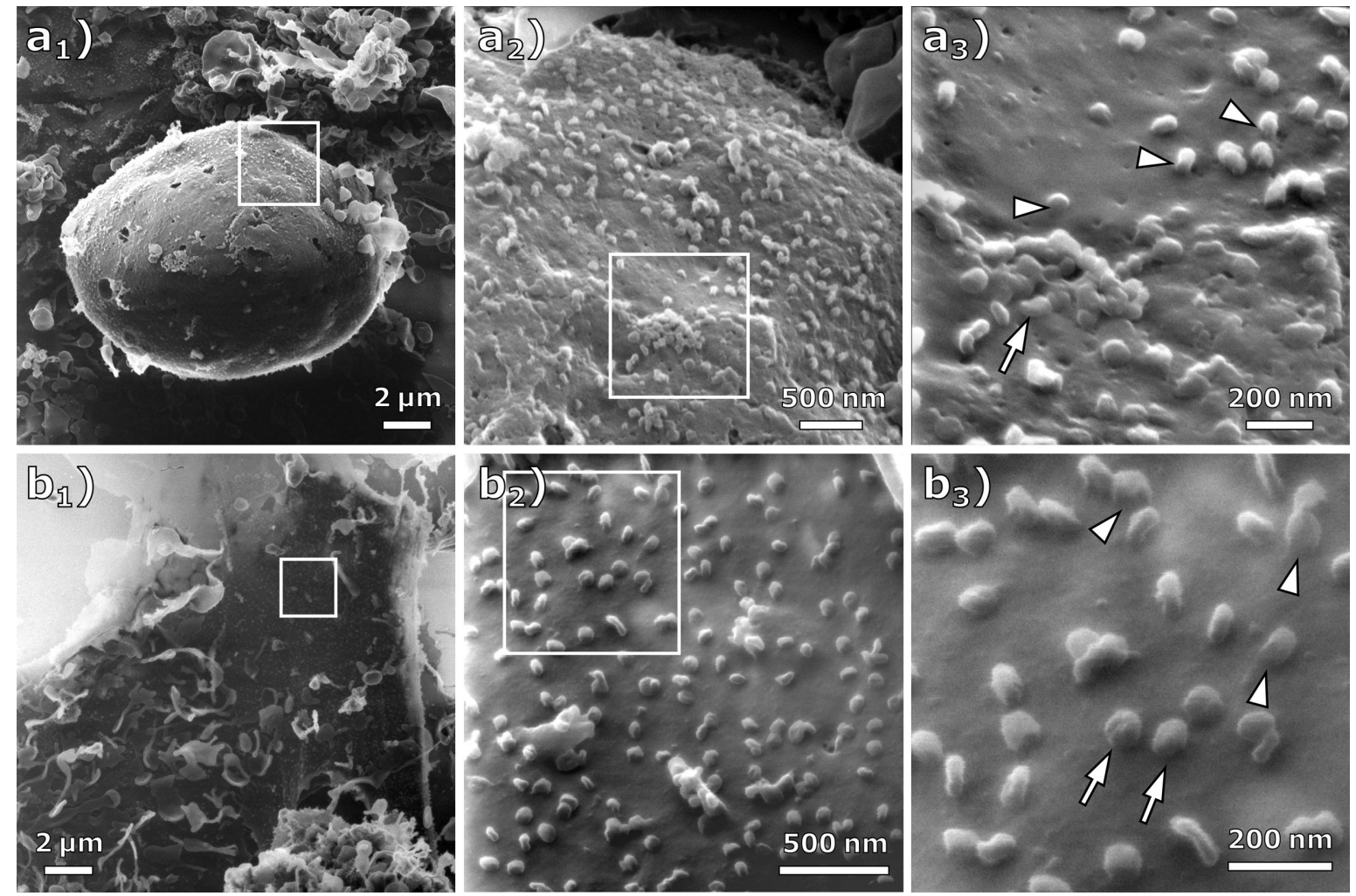

Figure 3: $\mathrm{HIM}$ images of cells infected at MOI 1 imaged with charge compensation. $\left(\mathrm{a}_{1-3}\right)$ Different magnifications of an infected cell (FOV $17 \mu \mathrm{m}$, $3.5 \mu \mathrm{m}$, and $1.3 \mu \mathrm{m}$ ). At the high magnification in $\left(\mathrm{a}_{3}\right)$, clusters of virus particles (arrow) and junctions (arrowheads) between the virus particle and the cell membrane become visible. ( $b_{1-3}$ ) Different magnifications of an infected cell (FOV $18 \mu \mathrm{m}, 2 \mu \mathrm{m}$, and $850 \mathrm{~nm}$ ). While some of the virus particles appear to be bound to the cell membrane (arrowheads), others seem to just lie on top of it (arrow). 
resembles the particle clustering by host defense protein BST-2 as it was observed for human coronavirus229E and quantified in HeLa cells by Wang and co-workers [38]. However, the metal coating applied by Wang et al. is clearly visible at high resolution in the SEM images as a rough layer on the cell membrane that hides the true topography $[25,39]$. In contrast, the HIM images presented here not only allow for the quantification of particles and clusters, but also enable an unveiled view on the interaction of virus particles with the cell membrane. The presented particle cluster seems to have a coalesced appearance, which might be caused by the virus-virus and virus-membrane interactions mediated through agglutinating BST-2 [40,41] Some viral particles appear to be connected to the cell membrane by a continuous junction (arrowheads). Figure $3 \mathrm{~b}$ shows another cell on the MOI 1 sample at different magnification levels. At the highest magnification shown in Figure $3 b_{3}$ (FOV $850 \mathrm{~nm}$ ), these junctions can also be observed (arrowheads). We assume that this resembles the tubulating cell membrane, which is stabilized by BST-2 to prevent viral scission. This alternative BST-2 interaction was already described for HIVinfected cells via immuno-TEM [42] but has not yet been observed for SARS-CoV-2. Aside from this observation, the HIM images allow for the distinction between viruses bound to the membrane and virus particles lying on top of the membrane (Figure 3b, arrows). Compared to a SEM study in which all visible virus particles on a cell membrane were quantified [38], HIM images could provide additional information about bound and unbound particles, resulting in more accurate data by counting only the bound particles. The presented images demonstrate that the HIM is well suited for the imaging of virus-membrane and virus-virus interactions, for example, when the virus particles are bound to the cell membrane or/and have a coalesced appearance.

It is known that the spike glycoproteins can be visualized by TEM. As the HIM images depicted the virus particles without conductive coating, it is an interesting question, whether or not the spike glycoproteins could, in principle, be resolved in HIM images. Inspecting the highest magnification images, Figure $2 b_{3}$ and Figure $2 c_{3}$, we do not see unequivocal evidence of structures indicating the spike glycoproteins. However, it is conceivable that a dedicated sample preparation could preserve their structure for imaging in HIM.

\section{Conclusion}

In this study, HIM images of Vero E6 cells without infection and infected with SARS-CoV-2 are presented. On infected cells, the ultrastructure of the cell-virus interaction, as well as interaction among virus particles, is shown. The absence of a previously applied conductive coating allows for the distinction between virus particles bound to the cell membrane and virus particles lying on top of the cell membrane. The images unveil the three-dimensional appearance of SARS-COV-2 and the surface of Vero E6 cells at MOI 1 with an edge resolution of up to $1.3 \mathrm{~nm}$. Additionally, it is shown that ion-induced deposition renders the sample surface sufficiently conductive to be imaged without charge compensation. The presented images demonstrate the potential of the HIM in bioimaging, especially for the imaging of interactions between viruses and their host organisms. HIM thus represents a versatile complement to conventional methods in the life sciences.

\section{Supporting Information}

\section{Supporting Information File 1}

Additional experimental data.

[https://www.beilstein-journals.org/bjnano/content/

supplementary/2190-4286-12-13-S1.pdf]

\section{Acknowledgements}

The authors thank André Beyer and Daniel Emmrich for valuable discussions.

\section{Funding}

F.W. is funded by the LOEWE Centre for Novel Drug Targets against Poverty-Related and Neglected Tropical Infectious Diseases (DRUID), which is part of the excellence initiative of the Hessen State Ministry of Higher Education, Research and the Arts (HMWK), the RAPID consortium of the Federal Ministry of Education and Research (BMBF, grant number 01KI1723E), and the European Union's Horizon 2020 research and innovation program under grant agreement No 101003666 (OPENCORONA). This work was further conducted within the framework of the COST Action CA19140 (FIT4NANO).

\section{ORCID ${ }^{\circledR}$ iDs}

Martin Wortmann - https://orcid.org/0000-0002-5101-4643 Matthias König - https://orcid.org/0000-0001-5877-6643 Friedemann Weber - https://orcid.org/0000-0001-9737-337X Holger Sudhoff - https://orcid.org/0000-0002-9274-5645 Armin Gölzhäuser - https://orcid.org/0000-0002-0838-9028

\section{Preprint}

A non-peer-reviewed version of this article has been previously published as a preprint: https://doi.org/10.3762/bxiv.2020.136.v1

\section{References}

1. Hlawacek, G.; Gölzhäuser, A., Eds. Helium Ion Microscopy; NanoScience and Technology; Springer International Publishing: Cham, Switzerland, 2016. doi:10.1007/978-3-319-41990-9 
2. Vanden Berg-Foels, W. S.; Scipioni, L.; Huynh, C.; Wen, X. J. Microsc. (Oxford, U. K.) 2012, 246, 168-176. doi:10.1111/j.1365-2818.2012.03606.x

3. BAZOU, D.; BEHAN, G.; REID, C.; BOLAND, J. J.; ZHANG, H. Z. J. Microsc. (Oxford, U. K.) 2011, 242, 290-294. doi:10.1111/j.1365-2818.2010.03467.x

4. Chen, X.; Udalagama, C. N. B.; Chen, C.-B.; Bettiol, A. A.; Pickard, D. S.; Venkatesan, T.; Watt, F. Biophys. J. 2011, 101, 1788-1793. doi:10.1016/j.bpj.2011.08.028

5. Rice, W. L.; Van Hoek, A. N.; Păunescu, T. G.; Huynh, C.; Goetze, B.; Singh, B.; Scipioni, L.; Stern, L. A.; Brown, D. PLoS One 2013, 8 , e57051. doi:10.1371/journal.pone.0057051

6. Schürmann, M.; Frese, N.; Beyer, A.; Heimann, P.; Widera, D.; Mönkemöller, V.; Huser, T.; Kaltschmidt, B.; Kaltschmidt, C.; Gölzhäuser, A. Small 2015, 11, 5781-5789. doi:10.1002/smll.201501540

7. Greiner, J. F. W.; Hauser, S.; Widera, D.; Müller, J.; Qunneis, F.; Zander, C.; Martin, I.; Mallah, J.; Schuetzmann, D.; Prante, C.; Schwarze, H.; Prohaska, W.; Beyer, A.; Rott, K.; Hütten, A.; Gölzhäuser, A.; Sudhoff, H.; Kaltschmidt, C.; Kaltschmidt, B. Eur. Cells Mater. 2011, 22, 403-419. doi:10.22203/ecm.v022a30

8. Leppänen, M.; Sundberg, L.-R.; Laanto, E.; de Freitas Almeida, G. M.; Papponen, P.; Maasilta, I. J. Adv. Biosyst. 2017, 1, 1700070. doi:10.1002/adbi.201700070

9. Said, N.; Chatzinotas, A.; Schmidt, M. Adv. Biosyst. 2019, 3, 1800250. doi:10.1002/adbi.201800250

10. Chen, S.-C.; Musat, N.; Lechtenfeld, O. J.; Paschke, H.; Schmidt, M.; Said, N.; Popp, D.; Calabrese, F.; Stryhanyuk, H.; Jaekel, U.; Zhu, Y.-G.; Joye, S. B.; Richnow, H.-H.; Widdel, F.; Musat, F. Nature 2019, 568, 108-111. doi:10.1038/s41586-019-1063-0

11. Schmidt, M.; Byrne, J. M.; Maasilta, I. J. Beilstein J. Nanotechnol. 2021, 12, 1-23. doi:10.3762/bjnano.12.1

12. Corman, V. M.; Lienau, J.; Witzenrath, M. Internist 2019, 60, 1136-1145. doi:10.1007/s00108-019-00671-5

13. Wu, F.; Zhao, S.; Yu, B.; Chen, Y.-M.; Wang, W.; Song, Z.-G.; Hu, Y.; Tao, Z.-W.; Tian, J.-H.; Pei, Y.-Y.; Yuan, M.-L.; Zhang, Y.-L.; Dai, F.-H.; Liu, Y.; Wang, Q.-M.; Zheng, J.-J.; Xu, L.; Holmes, E. C.; Zhang, Y.-Z. Nature 2020, 579, 265-269. doi:10.1038/s41586-020-2008-3

14. Coronavirus COVID-19 Dashboard, Johns Hopkins University. https://gisanddata.maps.arcgis.com/apps/opsdashboard/index.html\#/bd a7594740fd40299423467b48e9ecf6 (accessed Jan 18, 2021).

15. Takayama, K. Trends Pharmacol. Sci. 2020, 41, 513-517. doi:10.1016/j.tips.2020.05.005

16. Zhu, N.; Zhang, D.; Wang, W.; Li, X.; Yang, B.; Song, J.; Zhao, X.; Huang, B.; Shi, W.; Lu, R.; Niu, P.; Zhan, F.; Ma, X.; Wang, D.; Xu, W.; Wu, G.; Gao, G. F.; Tan, W. N. Engl. J. Med. 2020, 382, 727-733. doi:10.1056/nejmoa2001017

17. Algarroba, G. N.; Rekawek, P.; Vahanian, S. A.; Khullar, P.; Palaia, T.; Peltier, M. R.; Chavez, M. R.; Vintzileos, A. M. Am. J. Obstet. Gynecol. 2020, 223, 275-278. doi:10.1016/j.ajog.2020.05.023

18. Harcourt, J.; Tamin, A.; Lu, X.; Kamili, S.; Sakthivel, S. K.; Murray, J.; Queen, K.; Tao, Y.; Paden, C. R.; Zhang, J.; Li, Y.; Uehara, A.; Wang, H.; Goldsmith, C.; Bullock, H. A.; Wang, L.; Whitaker, B.; Lynch, B.; Gautam, R.; Schindewolf, C.; Lokugamage, K. G.; Scharton, D.; Plante, J. A.; Mirchandani, D.; Widen, S. G.; Narayanan, K.; Makino, S.; Ksiazek, T. G.; Plante, K. S.; Weaver, S. C.; Lindstrom, S.; Tong, S.; Menachery, V. D.; Thornburg, N. J. Emerging Infect. Dis. 2020, 26, 1266-1273. doi:10.3201/eid2606.200516
19. Bouhaddou, M.; Memon, D.; Meyer, B.; White, K. M.; Rezelj, V. V.; Correa Marrero, M.; Polacco, B. J.; Melnyk, J. E.; Ulferts, S.; Kaake, R. M.; Batra, J.; Richards, A. L.; Stevenson, E.; Gordon, D. E.; Rojc, A.; Obernier, K.; Fabius, J. M.; Soucheray, M.; Miorin, L.; Moreno, E.; Koh, C.; Tran, Q. D.; Hardy, A.; Robinot, R.; Vallet, T.; Nilsson-Payant, B. E.; Hernandez-Armenta, C.; Dunham, A.; Weigang, S.; Knerr, J.; Modak, M.; Quintero, D.; Zhou, Y.; Dugourd, A.; Valdeolivas, A.; Patil, T.; Li, Q.; Hüttenhain, R.; Cakir, M.; Muralidharan, M.; Kim, M.; Jang, G.; Tutuncuoglu, B.; Hiatt, J.; Guo, J. Z.; Xu, J.; Bouhaddou, S.; Mathy, C. J. P.; Gaulton, A.; Manners, E. J.; Félix, E.; Shi, Y.; Goff, M.; Lim, J. K.; McBride, T.; O'Neal, M. C.; Cai, Y.; Chang, J. C. J.; Broadhurst, D. J.; Klippsten, S.; De wit, E.; Leach, A. R.; Kortemme, T.; Shoichet, B.; Ott, M.; Saez-Rodriguez, J.; tenOever, B. R.; Mullins, R. D.; Fischer, E. R.; Kochs, G.; Grosse, R.; García-Sastre, A.; Vignuzzi, M.; Johnson, J. R.; Shokat, K. M.; Swaney, D. L.; Beltrao, P.; Krogan, N. J. Cell 2020, 182, 685-712.e19. doi:10.1016/j.cell.2020.06.034

20. Prasad, S.; Potdar, V.; Cherian, S.; Abraham, P.; Basu, A.; ICMR-NIV NIC Team. Indian J. Med. Res. 2020, 151, 241-243. doi:10.4103/ijmr.ijmr_577_20

21. Wolff, G.; Limpens, R. W. A. L.; Zevenhoven-Dobbe, J. C.; Laugks, U.; Zheng, S.; de Jong, A. W. M.; Koning, R. I.; Agard, D. A.; Grünewald, K.; Koster, A. J.; Snijder, E. J.; Bárcena, M. Science 2020, 369, 1395-1398. doi:10.1126/science.abd3629

22. Ward, B. W.; Notte, J. A.; Economou, N. P. J. Vac. Sci. Technol., B: Microelectron. Nanometer Struct.-Process., M eas., Phenom. 2006, 24, 2871. doi:10.1116/1.2357967

23. Hlawacek, G.; Veligura, V.; van Gastel, R.; Poelsema, B. J. Vac. Sci. Technol., B: Nanotechnol. Microelectron.: Mater., Process., Meas., Phenom. 2014, 32, 020801. doi:10.1116/1.4863676

24. "New Images of Novel Coronavirus SARS-CoV-2 Now Available", NIAID Media Team, Feb 17, 2020, USA.

https://www.niaid.nih.gov/news-events/novel-coronavirus-sarscov2-ima ges (accessed Dec 1, 2020).

25. Joens, M. S.; Huynh, C.; Kasuboski, J. M.; Ferranti, D.; Sigal, Y. J.; Zeitvogel, F.; Obst, M.; Burkhardt, C. J.; Curran, K. P.; Chalasani, S. H.; Stern, L. A.; Goetze, B.; Fitzpatrick, J. A. J. Sci. Rep. 2013, 3, 3514. doi:10.1038/srep03514

26. Rothe, C.; Schunk, M.; Sothmann, P.; Bretzel, G.; Froeschl, G.; Wallrauch, C.; Zimmer, T.; Thiel, V.; Janke, C.; Guggemos, W.; Seilmaier, M.; Drosten, C.; Vollmar, P.; Zwirglmaier, K.; Zange, S.; Wölfel, R.; Hoelscher, M. N. Engl. J. Med. 2020, 382, 970-971. doi:10.1056/nejmc2001468

27. Felgenhauer, U.; Schoen, A.; Gad, H. H.; Hartmann, R.; Schaubmar, A. R.; Failing, K.; Drosten, C.; Weber, F. J. Biol. Chem. 2020, 295, 13958-13964. doi:10.1074/jbc.ac120.013788

28. Bojkova, D.; Klann, K.; Koch, B.; Widera, M.; Krause, D.; Ciesek, S.; Cinatl, J.; Münch, C. Nature 2020, 583, 469-472. doi:10.1038/s41586-020-2332-7

29. Cohen-Tanugi, D.; Yao, N. J. Appl. Phys. 2008, 104, 063504. doi:10.1063/1.2976299

30. Bell, D. C. Microsc. Microanal. 2009, 15, 147-153. doi:10.1017/s1431927609090138

31. Ennos, A. E. Br. J. Appl. Phys. 1953, 4, 101-106. doi:10.1088/0508-3443/4/4/302

32. Isaacson, M. Ultramicroscopy 1979, 4, 193-199. doi:10.1016/s0304-3991(79)90193-1

33. Hren, J. J. Ultramicroscopy 1978, 3, 375-380. doi:10.1016/s0304-3991(78)80057-6 
34. van Gastel, R.; Barriss, L.; Sanford, C.; Hlawacek, G.; Scipioni, L.; Merkle, A. P.; Voci, D.; Fenner, C.; Zandvliet, H. J. W.; Poelsema, B. Microsc. Microanal. 2011, 17 (Suppl. 2), 928-929. doi:10.1017/s1431927611005514

35. Hlawacek, G.; Veligura, V.; Lorbek, S.; Mocking, T. F.; George, A.; van Gastel, R.; Zandvliet, H. J. W.; Poelsema, B. Beilstein J. Nanotechnol. 2012, 3, 507-512. doi:10.3762/bjnano.3.58

36. Veligura, V.; Hlawacek, G.; van Gastel, R.; Zandvliet, H. J. W.; Poelsema, B. Beilstein J. Nanotechnol. 2012, 3, 501-506. doi:10.3762/bjnano.3.57

37. Wirtz, T.; De Castro, O.; Audinot, J.-N.; Philipp, P. Annu. Rev. Anal. Chem. 2019, 12, 523-543. doi:10.1146/annurev-anchem-061318-115457

38. Wang, S.-M.; Huang, K.-J.; Wang, C.-T. Virology 2014, 449, 287-296. doi:10.1016/j.virol.2013.11.030

39. Caldas, L. A.; Carneiro, F. A.; Higa, L. M.; Monteiro, F. L.; da Silva, G. P.; da Costa, L. J.; Durigon, E. L.; Tanuri, A.; de Souza, W Sci. Rep. 2020, 10, 16099. doi:10.1038/s41598-020-73162-5

40. Mahauad-Fernandez, W. D.; Okeoma, C. M. Immun., Inflammation Dis. 2016, 4, 4-23. doi:10.1002/iid3.92

41. Berry, K. N.; Kober, D. L.; Su, A.; Brett, T. J. BioEssays 2018, 40, 1800086. doi:10.1002/bies.201800086

42. Hammonds, J.; Wang, J.-J.; Yi, H.; Spearman, P. PLoS Pathog. 2010, 6, e1000749. doi:10.1371/journal.ppat.1000749

\section{License and Terms}

This is an Open Access article under the terms of the Creative Commons Attribution License (https://creativecommons.org/licenses/by/4.0). Please note that the reuse, redistribution and reproduction in particular requires that the author(s) and source are credited and that individual graphics may be subject to special legal provisions.

The license is subject to the Beilstein Journal of Nanotechnology terms and conditions:

(https://www.beilstein-journals.org/bjnano/terms)

The definitive version of this article is the electronic one which can be found at:

https://doi.org/10.3762/bjnano.12.13 